Article

\title{
A New Method for Measuring Total Factor Productivity Growth Based on the Full Industry Equilibrium Approach: The Case of the Greek Economy
}

\author{
Nicholas Tsounis $1,2, *$ (D) and Ian Steedman ${ }^{3}$ \\ 1 Laboratory of Applied Economics, Department of Economics, University of Western Macedonia, \\ 52100 Kastoria, Greece \\ 2 Economic Analysis and Policy Lab, School of Social Sciences, Hellenic Open University, 26335 Patras, Greece \\ 3 Department of Economics, Manchester Metropolitan University, Manchester M15 6BH, UK; \\ steedman7@hotmail.com \\ * Correspondence: ntsounis@uowm.gr
}

Citation: Tsounis, Nicholas, and Ian Steedman. 2021. A New Method for Measuring Total Factor Productivity Growth Based on the Full Industry Equilibrium Approach: The Case of the Greek Economy. Economies 9: 114 https://doi.org/10.3390/economies 9030114

Academic Editor: Michele Meoli

Received: 24 June 2021

Accepted: 5 August 2021

Published: 16 August 2021

Publisher's Note: MDPI stays neutral with regard to jurisdictional claims in published maps and institutional affiliations.

Copyright: (c) 2021 by the authors. Licensee MDPI, Basel, Switzerland. This article is an open access article distributed under the terms and conditions of the Creative Commons Attribution (CC BY) license (https:/ / creativecommons.org/licenses/by/ $4.0 /)$.

\begin{abstract}
A new method of identifying the sources of output growth and measuring total factor productivity (TFP) is proposed, with an application to data from the Greek economy. The price accounting approach, based on the full industry equilibrium (FIE) framework introduced by Opocher and Steedman, where technical progress not only increases outputs relative to inputs but also reduces output prices relative to input rewards, is used. The contributions of this paper are that, first, it amends the FIE TFP measurement approach to account for heterogeneous labor inputs, imported inputs, and indirect taxes, and applies the method to real-world data from the Greek economy; second, it provides a comparison of the results with those found by the use of the neoclassical approach to TFP measurement arguing that the FIE approach measures better sectoral TFP change, and third, it provides an estimate of the effects of sectoral research and development $(R \& D)$ expenditures and R\&D diffusion from other sectors on TFP change for the Greek economy.
\end{abstract}

Keywords: total factor productivity growth; R\&D diffusion; full industry equilibrium

JEL Classification: O33; O47; D24

\section{Introduction}

Total factor productivity (TFP) change is an inherent and important part of both Solow's (1956) and Lucas (1988) and Romer's (1986, 1994) growth theories. It is recognized to be an important factor in both long-term economic growth and short-term growth fluctuations and is an important long-term factor in raising the living standards of a country. Since total factor productivity (TFP) is the portion of output not explained by the amount of inputs used in production, its level is determined by how efficiently and intensely the inputs are utilized in production.

There are thousands of studies on TFP growth in many countries; the following paragraphs review the most recent ones. Tsamadias et al. (2019) examined TFP growth among the OEDC countries, dividing the sample countries into two groups, the European Union (EU) members and the non-EU, to account for country heterogeneity for the period 1995-2015. Research and development (R\&D) expenditure and human capital (HC) were found to have a positive effect on TFP, while foreign direct investment (FDI) had a positive and significant effect only in the case of non-European countries. However, they found that the contribution of R\&D was considerably higher than that of HC and FDI in all cases. Pegkas et al. (2020) empirically analyzed the influence of domestic and foreign R\&D capital on TFP in Eurozone countries for the period 1995-2016. They discovered that variations in local and international R\&D capital accounted for TFP changes. Their findings demonstrate that R\&D capital has a beneficial impact on TFP. The contribution of foreign R\&D capital to 
TFP is higher than that of local R\&D capital. Sharif et al. (2021) focused on the Asia-Pacific region to analyze the impact of R\&D spending on TFP growth. The role of public and private $R \& D$ and their capacity to generate economic spillovers were examined. Their results show that the impact of both public and private $R \& D$ varies across countries. Huang et al. (2019) investigated how indigenous R\&D spending, as well as technological spillovers from foreign direct investments, export, and import, affected China's TFP. Their findings, which were based on Chinese provincial panel data encompassing 30 provinces from 2000 to 2014, demonstrate that indigenous R\&D investments play a key role in fostering TFP growth. There are also TFP growth benefits from technology spillovers caused by openness. However, the varied behaviors of these technology spillovers are determined by factors impacting technological absorptive capacity, such as human capital and domestic R\&D investments. Yue et al. (2019) added two environmental indicators into the TFP framework: ecological footprint, which reflects human ecological consumption, and human development index, which assesses human well-being levels. The indicator of sustainable total factor productivity takes into consideration ecological inputs such as energy consumption, built-up land use, and biological resource occupation, as well as the comprehensive outputs of economic growth, life expectancy, and educational attainment. From 1994 through 2014, data were collected for 55 countries. The findings demonstrate that, first, TFP change has a decreasing tendency, indicating that most states have placed less emphasis on long-term growth. The slow pace of sustainable technical advancement was the primary cause of the declining trend. Second, 19 of the 55 countries had a positive, long-term TFP increase and were able to maintain it. In a more recent article on this line of analysis, Shen et al. (2020) used a sustainable TFP growth index derived from translog production functions to assess the process of sustainable development. From 2006 to 2016, the sustainable TFP growth of 30 Chinese provinces was estimated. The findings reveal that China's TFP growth was modest, indicating poor long-term development. Second, variables including labor productivity and environmental legislation were shown to increase sustainable technological efficiency in a favorable way, but capital deepening, economic openness, and industrial structure harmed it. Third, TFP growth in China's regions showed a range of increasing tendencies, from high to low, in the order of western, central, and eastern regions. Four, the high incidence of economic imbalance was shown by the dispersion of TFP growth among provinces. Amri et al. (2019) investigated the linkage between carbon dioxide $\left(\mathrm{CO}_{2}\right)$ emissions, TFP, and information and communication technology (ICT) in Tunisia from 1975 to 2014. The results demonstrate the rejection of the Environmental Kuznets Curve (EKC) hypothesis by obtaining a higher value of the long-term TFP coefficient compared to the short-term one.

Furthermore, for the period 1990 to 2006, Haider et al. (2021) looked at how R\&D, trade, and ICT affected TFP growth in 25 European countries, Japan, and the United States. They broke down TFP growth into two components: catching up and innovation (frontier shifts). Frontier shifts tend to be lower with increasing distance from the frontier, and major disparities occur and remain between sectors and countries, although catching-up effects are statistically significant. Shabbir and Yaqoob (2019) calculated TFP for the India and Pakistan cotton production sector. Their findings demonstrate that in Pakistan, overall improvements in farm inputs have a more stable impact on cotton productivity, whereas in India, mechanization and area are the reasons for the sector's TFP rise. Saleem et al. (2019) investigated the factors that influence TFP and economic growth in Pakistan. For the period 1972-2016, TFP was calculated from an aggregate Cobb-Douglas production function. The findings show that innovation has a substantial impact on Pakistan's economic growth and output levels. TFP and its determinants were investigated in 420 agricultural firms in Vietnam by Giang et al. (2019). Agriculture is a crucial sector for the country's economic growth and poverty alleviation. Fixed and random effects models were used to calculate TFP. According to the study's results, reform efforts should concentrate on increasing the productivity of small agricultural businesses. Furthermore, they found that foreign investment, effective utilization of bank loans, and internet accessibility should all be improved to 
contribute to the country's long-term progress. Ngo et al. (2020) employed the generalized method of moments (GMM) to identify factors that affect TFP across 21 manufacturing sectors in Vietnam for the period 2010-2015. In several fragmentations of companies in terms of both labor and total capital, as well as in particular manufacturing sectors, the results reveal that large firms have much higher TFP levels than small enterprises. Doumi (2017) explored the evolution of TFP in the agricultural sector of ten Mediterranean countries for the period 1980-2012. The results show that Morocco experienced positive TFP change during the past two decades, ahead of Portugal and behind the rest of the countries in the sample. Kéita and Hannu (2021) investigated the link between corruption and taxation hampering TFP. The empirical study used panel data from 90 countries from 1996 to 2014. The results show that both corruption and tax burden deteriorate TFP.

All the above studies and the literature until now suggest TFP growth rate is residually determined (the famous Solow residual) after subtracting the growth rates of normally employed factor inputs, weighted by their income shares, from the output growth rate.

A completely different and novel approach to measuring TFP change is proposed here where TFP change measurement is based on decomposing the effects of technological progress on prices. This new method is based on the full industry equilibrium (FIE) framework introduced recently by Opocher and Steedman (2015) and on the pioneering work of Opocher (2010). FIE has its foundations in the modern classical economic theory and attempts to combine two competing approaches to microeconomics; namely, the neoclassical long-run theory of the firm and the Sraffa-inspired classical version of economics. Both approaches share some common ground, and their amalgamation may be profitably utilized to develop firmer theoretical conclusions of practical significance.

The FIE approach (or price accounting approach) achieves a synthesis between the two theories via the method of comparative statics analysis, according to which one starts with a state of equilibrium and then hypothesizes an exogenous change to a variable, such as, for example, the real wage (or profit rate), taxation, terms of trade, price of a strategic input (e.g., the price of oil), factor productivity, etc. Then the object of study becomes the movement of all relative prices which, following the aforementioned exogenous event, must change to be consistent with arriving at a situation of zero maximum profits earned by all industries. This is called, using a Wicksellian term, "full industry equilibrium" (FIE). The question at issue concerns predicting the sign of such price changes by taking into account the inter-industry structure of the economy and the attainment of the final equilibrium state, where there are no net (excess economic) profits. It is noteworthy that FIE differs from neoclassical general equilibrium since it is independent of consumer preferences or demand decisions associated with them.

In a FIE context, the firm in the industry competes with other similarly motivated firms for produced and non-produced inputs under the scheme of maximum net profits equal to zero. This is another methodological concession made to the standard neoclassical theory, according to which the mere presence of profits is sufficient to attract an inflow of firms until profits become equal to zero. In FIE the use of twice differentiable cost functions is often adopted and possible complementarities between inputs are often ruled out. In other words, the cost functions used in the analysis are assumed to be "well behaved". Competition leads to changes in the structure of relative commodity prices and, as far as the prices of primary inputs are concerned, it is possible to derive qualitative restrictions within the framework of comparative statics analysis ${ }^{1}$.

Taking into account the above, this paper examines the effects of total factor productivity (TFP) change on prices, under the FIE framework. These effects could be quite similar to those of taxation, but there is an important difference in that, while taxation is directly a policy variable, productivity is not. The TFP growth rate in neoclassical economics is residually determined after subtracting the growth rates of normally employed factor inputs, weighted by their income shares, from the output growth rate. The advantage of the FIE approach is that it breaks down the technical change measured by TFP into the changes in both average primary input prices and distribution. Moreover, FIE price 
accounting enables the identification of trend components of productivity in each industry. Lastly, the change in the primary input prices may be broken down to industry productivity change per se and to changes due to other industries.

The contributions of this paper are: (a) it introduces a completely new method for TFP measurement, based on the FIE, but extending FIE to account for heterogeneous labor inputs, imported inputs, and indirect taxes, and applies the method to real-world data from the Greek economy; (b) using econometric analysis it accounts for the effects of sectoral monopoly power on TFP changes, providing a comparison of the results with those found by the use of the neoclassical approach to TFP measurement; and (c) provides an estimate of the effects of technical change measured by sectoral research and development (R\&D) and diffused R\&D expenditures on sectoral TFP change for the Greek economy. Measuring productivity in each industry of the Greek economy by applying the FIE methodology has economic policy significance because it might show that the effects of technical progress on the disembodied productivity of the factors of production are different when the methodology used deviates from that of the orthodox neoclassical economic theory, and state intervention with targeted sectoral R\&D policy might be misleading if the latter has been used as a measurement of TFP. This could lead to quite different policy emphases concerning R\&D tax breaks and direct R\&D investments.

The paper proceeds as follows: Section 2 develops the methodology for the measurement of TFP change under the FIE approach and derives a comparable formula for the neoclassical TFP change. Data used for the empirical part of the paper are also described in this section. Section 3 describes and discusses the results and Section 4 concludes.

\section{Methodology and Data Description}

\subsection{The FIE Approach to Measuring TFP Change}

The full industry equilibrium (FIE) approach (Opocher and Steedman 2015) is an alternative for measuring sectoral TFP change.

When there is one primary factor input (labor), of the same quality across sectors, the TFP price accounting approach can be used as follows (ibid. pp. 158-63): Let $\underline{p}, \underline{\boldsymbol{u}}, \underline{\boldsymbol{l}}, \underline{\boldsymbol{A}}, w, c$ be the vector of commodity input prices, the unit vector, the vector of factor inputs per unit of output, the matrix of commodity inputs per unit of gross output, the factor price, and the indirect cost function, respectively (small bold letters indicate vectors and capital bold letters indicate matrices). Then

$$
\underline{\boldsymbol{p}}=c(w, \underline{\boldsymbol{p}} ; T) ; \text { where } T \text { indicates time. }
$$

By totally differentiating:

$$
\underline{\widehat{p}}=(\widehat{w} w \underline{\underline{l}}-\underline{\gamma})(\underline{\boldsymbol{I}}-\underline{\boldsymbol{A}})^{-1}
$$

where $\underline{\gamma} \equiv-\frac{\partial c}{\partial T} \frac{1}{c}$ is the rate if productivity growth. Since $w \underline{\boldsymbol{l}}=\underline{\boldsymbol{u}}(\underline{\boldsymbol{I}}-\underline{\boldsymbol{A}})$ then $\underline{\hat{p}}=\widehat{\widehat{w}} \underline{\boldsymbol{u}}-$ $\underline{\gamma}(\underline{I}-\underline{A})^{-1}$. TFP change for each sector can be calculated from vector $\underline{\gamma}{ }^{\wedge}{ }^{\wedge}$ indicates the rate of change.

We amend the indirect cost function above to account for many primary inputs and imported inputs:

$$
p_{j}=c_{j}\left(m_{j}, \underline{\boldsymbol{p}}, f_{j}, t_{j} ; T\right)
$$

where $m, \boldsymbol{p}, f, t, c$ are monetary wage, the vector of commodity input prices, the value of imported inputs, net indirect taxes (assuming that prices are expressed at a consumer level and include net indirect taxes), and the indirect cost function, respectively. $T$ indicates time.

By totally differentiating (1) it is derived that:

$$
\dot{p}_{j}=l_{j} \dot{m}_{j}+\sum_{i=1}^{n} \alpha_{i j} \dot{p}_{i}+b_{j} \dot{f}_{j}+z_{j} \dot{t}_{j}+\frac{\partial c_{j}}{\partial T}
$$


Dotted variables denote change $(d()) ;$.$l is the primary input coefficient, b$ and $z$ are input coefficients for imported inputs and net indirect taxes, and $n$ is the number of sectors; (2), in a rate of change terms denoted by a hat become:

$$
\widehat{p}_{j}=\left(\frac{m_{j} l_{j}}{p_{j}}\right) \widehat{m}_{j}+\sum_{i}\left(\frac{a_{i j} p_{i}}{p_{j}}\right) \widehat{p}_{i}+\left(\frac{b_{j} f_{j}}{p_{j}}\right) \widehat{f}_{j}+\left(\frac{z_{j} t_{j}}{p_{j}}\right) \widehat{t}_{j}-\gamma_{j}
$$

where $\gamma_{j} \equiv \frac{\partial c_{j}}{\partial T} \frac{1}{\partial c_{j}}, j$ denotes sector $j$ and ^ indicates the rate of change. $\gamma_{j}$ is TFP change in sector $j$.

In (3), by replacing the share of wages of sector $j$ in gross output with $\sigma_{j}^{*}$, the share of imports of $j$ sector in gross output with $\beta_{j}^{*}$, the share of net indirect taxes of $j$ in gross output with $\zeta_{j}^{*}$, and $\frac{a_{i j} p_{i}}{p_{j}}$, the value of input $i$ in the value of one unit of output $j$ with $\alpha_{j}^{*}$, we get:

$$
\widehat{p}_{j}=\sigma_{j}^{*} \widehat{m}_{j}+\sum_{i} \alpha_{i j}^{*} \widehat{p}_{i}+\beta_{j}^{*} \widehat{f}_{j}+\zeta_{j}^{*} \widehat{t}_{j}-\gamma_{j}
$$

or

$$
\widehat{p}_{j}=\sigma_{j}^{*} \widehat{m}_{j}+\widehat{p} A_{j}^{*}+\beta_{j}^{*} \widehat{f}_{j}+\zeta_{j}^{*} \widehat{t}_{j}-\gamma_{j}
$$

where $A_{j}^{*}$ is the $j$ th column of the $A^{*}$ matrix of commodity inputs per unit of gross output expressed in unit values. Equation (4) decomposes percentage change in product price of sector $j$ to its components: the first RHS term is the effect of change in factor rewards, the second the relative change in the prices of produced inputs effect, the third is the effect in the terms of trade change, and the fourth the effect from a change in net indirect taxes. $\gamma_{j}$ is the TFP change in the sector.

Solving (4) for $\gamma_{j}$ we get:

$$
\gamma_{j}=\sigma_{j}^{*} \widehat{m_{j}}+\widehat{p} A_{j}^{*}+\beta_{j}^{*} \widehat{f}_{j}+\zeta_{j}^{*} \widehat{t}_{j}-\widehat{p}_{j}
$$

Apart from the factors in (1) that affect prices, economic theory, since Lerner (1934), has proven that monopoly power has a rising effect on prices. Although FIE assumptions considered that all sectors are in a long-run equilibrium with zero profit rates, in the real world this assumption might be quite unrealistic. Therefore, since the TFP change calculation in (5) is based on price change rates, the effects of sectoral monopoly power on prices must be accounted for. Monopoly power is usually measured, in empirical studies, by an industry's concentration using the Herfindahl-Hirschman index (Hirschman 1964). However, the calculation of the latter requires information on the market shares of each individual firm in each sector and such disaggregated data are not available for the Greek economy. As an alternative, for measuring sectoral concentration, the Schmalensee (1977) firms concentration index is used from the following formula:

$$
S I_{j}=\frac{\left(A S_{j 1}-A S_{j 2}\right)^{2}\left(n_{j 1}^{2}-1\right)}{3 n_{j 1}}+n_{j 1} A S_{j 1}^{2}+\left(n_{j}-n_{j 1}\right) A S_{j 2}^{2}
$$

where $A S_{j 1}, A S_{j 2}, n_{j}$ are the average market shares of the five first in terms of sales firms, the average market shares of the remaining firms in sector $j$, and the total number of firms in sector $j$, respectively. $n_{j 1}$ is the number of the largest firms in sector $j$ and in our case is set equal to five. An increase in sectoral concentration is an indication of an increase in monopoly power; therefore, a positive relationship is expected between changes in prices and the change in market concentration. From Equation (5) it can be observed that the TFP change rate of a sector $j\left(\gamma_{j}\right)$ is affected negatively by the change rate of prices in that sector.

To account for the effect of the change rate in monopoly power of a sector on the TFP change rate, $\gamma_{j}$ s are regressed on $\widehat{S I}_{j}$ :

$$
\gamma_{j}=\mathrm{a}_{1}+\mathrm{b}_{1} \widehat{S I}_{j}+u_{j}
$$


$u_{j}$ is the disturbance term. The residuals of this regression are the sectoral TFP change rates $\left(\gamma_{j}\right.$ 's) without the effect the change in monopoly power on price change rates. The expected sign of the estimated coefficient of $\widehat{S I}_{j}$ is negative. The results are reported in Section 3, below.

Several studies have theoretically and empirically identified factors that determine TFP (see Silveira et al. 2021 for a review of literature of TFP determinants). Theory suggests that human capital (ibid; Arazmuradov et al. 2014; Danska-Borsiak 2018; Akinlo and Adejumo 2016), trade (Bhattacharya et al. 2021; Kim 2016), FDI/imports (Bhattacharya et al. 2021; Kim 2016; Akinlo and Adejumo 2016; Harris and Moffat 2020), and R\&D expenses (Danska-Borsiak 2018; Otsuka 2017; Kim 2016) are the main determinants of TFP growth. However, it is recognized that the latter is the main driver of TFP growth (among others, Saleem et al. 2019; Huang et al. 2019; Shabbir and Yaqoob 2019; Sharif et al. 2021; Pegkas et al. 2020; Tsamadias et al. 2019; Haider et al. 2019; Griliches 1979, 1994; Griffith et al. 2004; Edquist and Henrekson 2006; Hall et al. 2009; Eberhardt et al. 2013; Donghyun et al. 2014; Gehringeer et al. 2015; Venturini 2015) because it facilitates the adoption and implementation of new technologies exogenously facilitating the domestic production of technological innovations. Productivity gains are linked to R\&D diffusion because innovative producers are more receptive to new technologies and thus can maximize gains and reduce costs.

Therefore, R\&D is recognized to be the main driver of TFP growth as it is the most commonly used measure of technical change. Direct $R \& D$ expenditure affects the innovative capacity of a sector both directly and indirectly by increasing its absorptive capacity for knowledge created in other sectors. The relationship between TFP change rates calculated by FIE $\left(\gamma_{j}^{\prime}\right.$ s) and R\&D expenditure was examined by the regression of $\gamma_{j}^{\prime}$ 's on total sectoral R\&D expenditure over the period for which the $\gamma_{j}$ 's are calculated, i.e., 2010-2015. A variable $\left(R D \_D I F_{j}\right)$ measuring $R \& D$ diffusion from the total $R \& D$ expenditure of other sectors of the economy into sector $j$ (indirect R\&D expenditure or embodied R\&D) was also included in the model ${ }^{2}$.

$$
\gamma_{j}^{\prime}=c_{1}+d_{1} \log \left(R D_{j}\right)+d_{2} \log \left(R D_{-} D I F_{j}\right) .
$$

Equation (7) is in semi-log form because it is convenient that the coefficient of total sectoral $R \& D$ be interpreted as elasticity $\left(\gamma_{j}{ }^{\prime}\right.$ s are already expressed in percentage change rates). The estimated R\&D coefficients $d_{1}$ and $d_{2}$ are expected to be positive and statistically significant.

\subsection{The Neoclassical Framework for Measuring TFP Change}

TFP growth rate in neoclassical economics is residually determined after subtracting the growth rates of normally employed factor inputs, weighted by their income shares, from the output growth rate. An attempt is made here to review this method and amend it to be comparable to Equation (5). The literature on the issue is quite extensive. Both theoretical and empirical studies measure TFP as an indication of disembodied technical progress caused by R\&D and R\&D spillovers. Several literature reviews cover the subject (among others, Gollop and Jorgenson (1980); Mohnen (1989); Kydland and Prescott (1982); Griliches (1992); Coe and Helpman (1993); Bernstein and Mohnen (1994); Nadiri (1993); Katsoulacos and Tsounis (2000); Athanasoglou et al. (2008); Sakurai et al. (1996); Vamvakidis (2002); Aulin-Ahmavaara (2004); Vournakis (2007); Jones and Romer (2010); Sheng and Song (2013); Voutsinas and Tsamadias (2014); Gogos et al. (2013); Comin (2010); Haider et al. (2021); Próchniak (2016); Manasse (2016)).

Usually, TFP is expressed as production per unit of a composite index of inputs, appropriately aggregated. Two methods can be distinguished in the literature to calculate TFP: the growth accounting approach and the production function approach. Both methods produce the same results under the assumption of constant returns to scale and perfect competition in product and factor markets. TFP growth then corresponds to the concept of 
technical change which causes shifts in the production function, distinct from movements along the production function caused by factor substitution due to changes in relative factor prices (Jorgenson and Griliches 1967).

The growth accounting approach with input-output data will be used here. The use of input-output accounts allows the identification of a detailed cost structure in a given industry, covering the production structure of both primary and intermediate inputs. A word of caution is required regarding TFP indicators; they do not exactly correspond to technical change if competition does not prevail in both products and factor markets, or there are regulations distorting competition and/or externalities that cause scale economies. In particular, the effect of economies of scale is likely to be a major part of productivity growth in capital-intensive industries. In practice the distinction between economies of scale and pure technical change is difficult, but in theory, the contribution of economies of scale is distinguished from that of technical change in productivity growth.

TFP, for a sector or the economy as a whole, is generally defined as the ratio of the volume of production $Y$ relative to the total volume of input $X$, i.e., $T F P=\frac{Y}{X}$. Therefore, the growth rate of TFP is computed as:

$$
\frac{T \dot{F P}}{\mathrm{TFP}}=\frac{\dot{Y}}{\mathrm{Y}}-\frac{\dot{X}}{\mathrm{X}}
$$

where the dot indicates change (it can be seen also as the first derivative against time, i.e., for $Y, \dot{Y}=\frac{d Y}{d t}$ etc). From Equation (8) it is seen that TFP growth is a residual between the rate of change in production and the rate of change in production inputs.

TFP change then is calculated as the change in output growth between two distinct points in time when all the remaining sources of output growth are subtracted. Therefore, we can identify apart from TFP, the contribution of primary factor productivity change in output growth, the contribution of capital, and the contribution of intermediate inputs of domestic and of imported origin. When examining Equation (8) for several successive points in time, substitution effects among inputs (intermediate of domestic and imported origin and labor and capital) can also be identified.

It is known that using value-added instead of gross output is a better indication of resource allocation ${ }^{3}$. Consequently, the value-added approach will be used here for measuring the TFP change according to the neoclassical approach.

Let

$$
Y_{j}^{V A}=p_{j} Y_{j}-\sum_{i} p_{i} X_{i}-\sum_{i} t_{i} X_{i}-\sum_{i} p_{i}^{m} X_{i}^{m}
$$

be the value-added output of sector $j$ at factor cost. $Y$ denotes final product in physical units, $X$ intermediate inputs in physical units, subscripts denote sectors, superscript $\mathrm{m}$ denotes imports, $p$ denotes price, and $t$ net indirect taxes per unit of product. Further,

$$
\frac{T \dot{F} P_{j}}{T F P_{j}}=\widehat{T F P_{j}}=\frac{\partial Y_{j}^{V A}}{\partial \mathrm{T}} \frac{1}{Y_{j}^{V A}}=\left(\frac{\partial Y_{j}}{\partial \mathrm{T}} \frac{1}{Y_{j}}\right) \frac{p_{j} Y_{j}}{Y_{j}^{V A}}
$$

By totally differentiating Equation (9), substituting from Equation (8), and solving for $\widehat{T F P}_{j}$ we get:

$$
\widehat{T F P_{j}}=\widehat{Y_{j}^{V A}}-\sum_{i}\left(\frac{w_{i} L_{i}}{Y_{j}^{V A}} \widehat{L_{j}}\right)-\frac{Y_{j} p_{j} \widehat{p}_{j}}{Y_{j}^{V A}}+\sum_{i}\left(\frac{X_{i} p_{i}}{Y_{j}^{V A}} \widehat{p}_{i}\right)+\sum_{i}\left(\frac{X_{i}^{m} p_{i}^{m}}{Y_{j}^{V A}} \widehat{p_{i}^{m}}\right)+\sum_{i}\left(\frac{X_{i} t_{i}}{Y_{j}^{V A}} \widehat{t_{i}}\right)
$$

By substituting in Equation (11) $l_{i}^{*}, y_{j}^{*}, x_{i}^{*}, m_{i}^{*}$ and $t_{i}^{*}$-the share of the value of the $i$ th labor input in value-added $j$, the ratio of the value of output $j$ over value-added $j$, the share of the value of domestic inputs in value-added $j$, the share of the value of imported inputs in value-added $j$ and the share of net indirect taxes in value-added $j$, respectively-we get:

$$
\widehat{T F P}=\widehat{Y_{j}^{V A}}-\sum_{i} l_{i}^{*} \widehat{L}_{j}-y_{j}^{*} \widehat{p}_{j}+\sum_{i} x_{i}^{*} \widehat{p}_{i}+\sum_{i} m_{i}^{*} \widehat{p_{i}^{m}}+\sum_{i} t_{i}^{*} \widehat{t_{i}}
$$


As can be seen, in Equation (12) $\widehat{T F P}$ depends on $\widehat{p}_{j}$ and therefore, the effects of monopoly power on sectoral TFP change rate have to be accounted for. So, an estimation similar to Equation (6) has been performed:

$$
\widehat{T F P}=\alpha_{2}+\beta_{2} \widehat{S I}_{j}+v_{j}
$$

The residuals of this regression are the sectoral TFP change rates without the effect of change of monopoly power on price change rates $\left(\widehat{T F P_{j}^{\prime}}\right) .4$ The expected sign of the coefficient again is negative. This can be derived easily from Equation (12); empirical studies examining the relationship between TFP change and change in sectoral concentration establish also a negative relationship (Bournakis 2012; Tsekouras and Daskalopoulou 2006). The results are reported in Appendix B. Equation (7) is estimated again with $\widehat{\mathrm{TFP}_{j}^{\prime}}$ as the dependent variable. A comparison of the estimation results of the two regressions will indicate which TFP methodology measures better technical progress caused by R\&D expenditure, the neoclassical or FIE.

\subsection{Data Description}

Both FIE and neoclassical methods of TFP measurement have been applied to realworld data from the Greek economy to provide a comparison of the results between the two methods. As a background, we quickly remind the reader about the macroeconomic indicators in Greece during the studied period of 2010 to 2015. During this period Greece was struck by a deep recession as a result of the adjustment program imposed by the Troika to deal with the huge budget deficit and sovereign debt crisis following the 2008 financial crisis. The average annual real GDP growth for the period was $-3.93 \%$, the average price changes over the period were $-2.3 \%$, the average annual unemployment rate was $24.2 \%$ of the labor force, and the average annual current account balance was USD -9.9 billion (IMF 2021). Furthermore, there was an emigration of the most skilled and qualified individuals together with a fall in employment coupled with wage cuts of $22.5 \%$ to $23.2 \%$ dictated by the Troika (Agiomirgianakis et al. 2019).

The choice of the Greek economy was made for two reasons: (a) data availability, and (b) suitable macroeconomic indicators for making a comparison between the FIE and the neoclassical methods. Regarding the first reason, the use of Equation (5) for empirical work requires that input-output (i-o) table data report also labor inputs in physical terms; i.e., total hours worked per sector. These kinds of data are not available in the $\mathrm{i}-\mathrm{o}$ tables reported for the EU countries by Eurostat and the OECD and were available for the Greek economy for the two years of the study only. Secondly, macroeconomic indicators for Greece during the examined period made the country ideal to compare the results of TFP growth calculated according to the new method introduced here (FIE) and the neoclassical one because according to theory ${ }^{5}$, when prices decrease, the neoclassical approach would underestimate TFP changes.

Sixty-four sector input-output tables of the Greek economy using the NACE rev.2 classification scheme for 2010 and 2015 (Hellenic Statistical Authority 2010, 2015) were used for the calculation of both the neoclassical and FIE approaches to sectoral TFP change. Output and import price data for the 64 sectors of the input-output tables were also extracted from Hellenic Statistical Authority (2016a, 2016b). Total sales data of the largest firms in each sector and total sectoral sales for the calculation of the Schmalensee index were obtained from the Hellenic Statistical Authority after special request (these data are not publicly available). Sectoral R\&D expenditure data in constant prices for the period 2011-2015 were extracted from the OECD database (OECD 2011-2015).

\section{Results and Discussion}

Equations (5) and (12) were applied to the dataset and then Equation (6) was estimated to isolate the effect of change in monopoly power on sectoral TFP changes. Estimation results were checked for robustness by estimating Equation (6) using $\gamma_{j}$ values calculated by 
input-output table data from the two different years, 2010 and 2015. Therefore, Equation (5) was calculated using $A_{j^{*}}$ from both 2010 and 2015 input-output tables. The $2010 \gamma_{j}^{\prime}$ values can be called "Laspeyres values" as they use for their calculation the earlier year, while the $2015 \gamma^{\prime}{ }_{j}$ values can be called "Paasche values" as they use for their calculation the more recent year. The results from the estimation of Equation (6) are presented in Appendix A together with the estimation diagnostics (Breusch-Pagan heteroskedasticity test, JarqueBera normality test, and statistical significance of the coefficients). The robustness check led to the conclusion that the estimated coefficient values using Laspeyres and Paasche $\gamma_{j}^{\prime} \mathrm{s}$ and their statistical significance are almost identical.

Figure 1 depicts the $\gamma^{\prime}$ values using data from the two years. As can be seen, most of them are on the $45^{\circ}$ line. The Pearson correlation coefficient between the Laspeyres and Paasche $\gamma_{j}^{\prime} \mathrm{s}$ is 0.916 , its t-statistic 17.98, and it is statistically significant at zero level of statistical significance. Additionally, the ranking of industries using the two types of $\gamma_{j}^{\prime}$ index is almost identical; the Spearman rank correlation coefficient has a value of 0.966 , with a t-statistic of 29.37 and it is statistically different from zero at zero level of statistical significance. Detailed descriptive statistics are reported in Table 1. The means for the indexes calculated using the production structure for both years are very close to their medians, indicating that there are not many outlier values.

Table A3 in Appendix B presents the results of the TFP change in the 64 sectors using the FIE approach using 2010 (Laspeyres $\gamma_{j}^{\prime}$ ) and 2015 (Paasche $\gamma_{j}^{\prime}$ ) as base years. The terms of trade effect $\left(\beta_{j}^{*} \widehat{f}_{j}\right.$ in (5)) is also reported in separate columns. Thirty-three out of 64 sectors experienced a positive change in TFP while the remaining 31 sectors experienced a negative change. The first five sectors with the highest TFP change were services sectors $(61,44,45,33,60)$ followed by transport equipment $(21)$, chemical products (11), printing and recording services (9), and products of forestry, logging, and related services (2). Of the 33 sectors with a positive change in their TFP, 13 were services sectors. The highest negative change in TFP was experienced by the refined petroleum products and coke (10) and employment services (52) industries, while 21 of the 31 sectors with negative TFP change were also services sectors including telecommunication services (39), education services (56), and financial services (41).

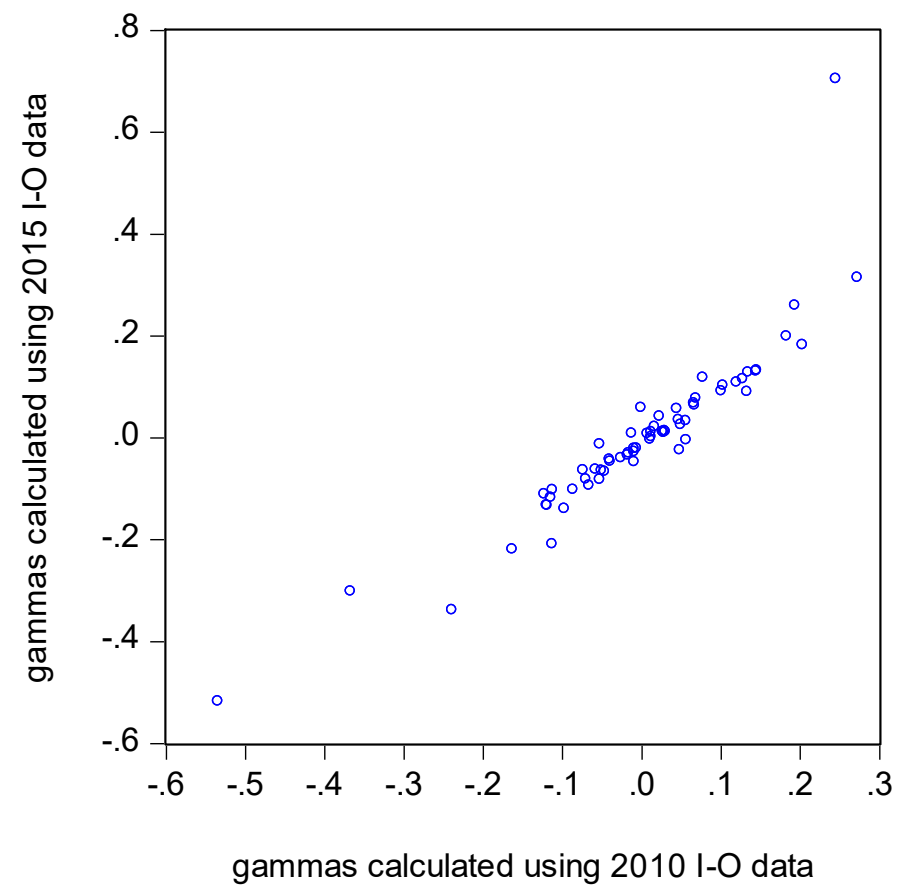

Figure 1. $\gamma_{j}^{\prime}$ s scatter diagram calculated with 2010 and $2015 A_{j^{*}}$. Source: Authors' calculations. 
The median value of the terms of trade contribution to the total price change was 0.057. In 40 sectors, the contribution of the terms of trade change to total prices change was less than $10 \%$. These results can be attributed (a) to the degree of openness of the Greek economy; it is a relatively closed economy (its openness index has a value of about $40 \%$ ) relative to the other EU countries (with an openness index of more than $70 \%$ ), and (b) to the fact that international prices do not change much over five years. The sectors with the highest terms of trade effect on prices were pharmaceutical products (12), non-metallic mineral products (14), and machinery and equipment (19). Production of these sectors relies heavily on imported inputs.

We will now turn to compare the results with those found by the use of the neoclassical approach to TFP measurement. It is argued in Opocher and Steedman (2015) that when prices decrease, the neoclassical approach would underestimate the true rate of valueadded TFP increase ${ }^{6}$. During the period 2010-2015 the average price change in all sectors was $-2.295 \%$ (with a median of $-2.825 \%$ ). Therefore, neoclassical TFP changes were expected to be lower, on average, than the $\gamma$ s calculated according to FIE. To test this hypothesis, the mean and median values of the TFP change calculated according to the neoclassical and FIE approaches were compared ${ }^{7}$. For robustness, both the Laspeyres and Paasche methods were used in the test.

Table 1. Mean and median values of TFP change over the period 2010-2015 calculated according to the neoclassical and FIE approaches.

\begin{tabular}{cccc}
\hline & $\widehat{\mathbf{T F P}^{\prime}}$ & $\gamma^{\prime}$ Laspeyres & $\gamma^{\prime}$ Paasche \\
\hline Mean & -0.061147 & $3.47 \times 10^{-18}$ & $5.20 \times 10^{-18}$ \\
\hline Median & -0.028878 & 0.008359 & 0.000137 \\
\hline Source: Authors' calculations (extracted from Appendix A). &
\end{tabular}

As can be seen from Table A3, the FIE approach yields, on average, higher values of TFP change than the neoclassical approach. Further, a test for equality of the means and medians of Table A3 was conducted to test whether the observed difference in means and medians was statistically significant. As can be seen from Appendix $C$, the difference in means and medians was statistically significant at a convenient (5\%) level of statistical significance, which empirically confirms the prediction by theory.

Therefore, measuring sectoral total productivity change in the Greek economy by applying the FIE methodology has economic policy significance because it produces different estimates than the neoclassical one. This finding also affects the study of the effects of technical progress on TFP change, which may be different when the neoclassical methodology is used. Consequently, it is suggested that sectoral characteristics should be considered by the government in establishing relevant policies for enhancing sectoral productivity; generally, governments would like to focus their attention, with production enhancing measures, to sectors that produce positive rates of growth, contributing to the average growth of the economy. Specifically, by examining and comparing the results of Tables A3 and $A 4$, it is seen that during the examined period characterized by a great depression for the Greek economy, TFP growth rates were systematically underestimated when using the neoclassical method of measurement. As a result, fifteen sectors that exhibited positive TFP growth measured according to the approach proposed here would have been considered as sectors with negative TFP growth if the standard in the literature approach had been used, misleading policymakers to divert measures away from these sectors ${ }^{8}$ and hampering the overall growth rate of the economy.

The knowledge produced outside a sector, in other sectors of the same economy or abroad, may be important for sectoral TFP change. We tested the hypothesis that the main drivers of TFP change lie with the R\&D conducted within a sector and the R\&D diffused by other sectors into the sector. For testing this hypothesis, Equation (7) was used and the results are reported in Table 2. 
Ex ante, one may expect that R\&D diffused by other sectors is related to the $R \& D$ conducted within a sector, since the absorptive capacity of new knowledge is related to the level of knowledge existing in a sector. If the relation between the regressors of the model is high, it will cause a multicollinearity problem in the estimation of Equation (7). The presence of multicollinearity affects the variance of the estimated coefficients but not their value. The variance inflation factors (VIF) test was conducted to ensure that the correlation between regressors did not affect significantly the variance of the coefficients (and therefore, their statistical significance). VIF is a method of measuring how much the variance of an estimated regression coefficient is increased due to collinearity. If VIF is less than 5 then it is accepted that multicollinearity is not high (Sheather 2009). The VIF for the coefficients of $\log \left(R D_{j}\right)$ for all models was about 1.60 (second column, Table 2) and for the coefficients of $\log \left(R D_{-} D I F_{j}\right)$ about 1.09 (third column, Table 2). Therefore, VIF for all estimated coefficients in all models was less than 5 and it is concluded that multicollinearity is not a problem in the estimation of Equation (7).

Table 2. Estimation results from Equation (7).

\begin{tabular}{|c|c|c|c|c|c|c|c|}
\hline $\begin{array}{c}\text { Dependent } \\
\text { Variable }\end{array}$ & $\begin{array}{c}\text { Regressand } \\
\log \left(R D_{j}\right) \\
\text { Coefficient } \\
\text { (Probability) } \\
\text { VIF }\end{array}$ & $\begin{array}{l}\text { Regressand } \\
\log \left(R D_{\_} D I F_{j}\right) \\
\text { Coefficient } \\
\text { (Probability) } \\
\text { VIF }\end{array}$ & $\begin{array}{c}\text { Intercept } \\
\text { Coefficient } \\
\text { (Probability) }\end{array}$ & $R^{2}$ adj & AIC & $\begin{array}{c}\text { Breusch-Pagan- } \\
\text { Godfrey } \\
\text { Heteroskedasticity } \\
\text { Test: F-Statistic (Prob. } \\
\text { F(1,62)) }\end{array}$ & $\begin{array}{c}\text { Jarque-Bera } \\
\text { Normality } \\
\text { Test } \\
\text { (Probability) }\end{array}$ \\
\hline$\gamma_{j}^{\prime}$ Laspeyres & $\begin{array}{c}0.371130 \text { ** } \\
(0.0000) \\
1.598850\end{array}$ & $\begin{array}{c}0.1218666^{* *} \\
(0.0095) \\
1.089770\end{array}$ & $\begin{array}{c}0.301901 \text { * } \\
(0.0286)\end{array}$ & 0.340701 & -3.0355 & $\begin{array}{c}0.002124 \\
(0.9634)\end{array}$ & $\begin{array}{c}74.66734 \\
(0.0000)\end{array}$ \\
\hline$\gamma_{j}^{\prime}$ Paasche & $\begin{array}{c}0.290525 * * \\
(0.0009) \\
1.585329\end{array}$ & $\begin{array}{c}0.0936677^{* *} \\
(0.0004) \\
1.080817\end{array}$ & $\begin{array}{c}0.430790 * \\
(0.0430)\end{array}$ & 0.245685 & -2.6107 & $\begin{array}{c}0.996554 \\
(0.3220)\end{array}$ & $\begin{array}{c}33.14470 \\
(0.0000)\end{array}$ \\
\hline$\widehat{T F P}_{j}^{\prime}$ & $\begin{array}{c}0.097113^{+} \\
(0.0865) \\
1.598755\end{array}$ & $\begin{array}{c}0.057560 * \\
(0.0321) \\
1.089971\end{array}$ & $\begin{array}{c}0.046521^{+} \\
(0.0525)\end{array}$ & 0.149678 & -1.0502 & $\begin{array}{c}0.263140 \\
(0.6098)\end{array}$ & $\begin{array}{c}5698.413 \\
(0.0000)\end{array}$ \\
\hline
\end{tabular}

$* * *,+$ statistically different from zero at least at $1 \%, 5 \%$, and $10 \%$ level of statistical significance, respectively; AIC: Akaike information criterion is a measure of the relative quality of a statistical model for a given set of data and, therefore, it provides a means for model selection. Source: Authors' estimations.

$R D_{j}$ is sectoral total $R \& D$ expenditure, in constant prices, for the period 2011-2015 and $R D \_D I F_{j}$ is $R \& D$ diffusion from the total $R \& D$ expenditure of other sectors of the economy into sector $j$ (indirect R\&D expenditure or embodied R\&D). As can be seen from the last two columns, the residuals from all three estimations passed the normality and heteroskedasticity tests. R\&D expenditure coefficients estimated by using TFP change calculated by the FIE method were consistently higher than those estimated by the neoclassical method and their statistical significance is also higher. Furthermore, both models with FIE measures performed better than the model with the neoclassical measure of sectoral TFP change in terms of adjusted $\mathrm{R}^{2}$ and $\mathrm{AIC}^{9}$ which, in turn, implies that the FIE method of measurement TFP change is better than the neoclassical one. The estimated coefficient of the R\&D expenditure variable found using the neoclassical method of TFP change (0.097) was within the range value of the coefficients found by other studies for the Greek economy (0.0192 to 0.127) (Bournakis 2012; Voutsinas and Tsamadias 2014; Gogos et al. 2013; Tsekouras and Daskalopoulou 2006). The results (Table 2) indicate that sectoral TFP change depends on R\&D expenditure, both in the form of direct sectoral investment and indirect, diffused by other sectors. A comparison of the values of the coefficients shows that direct sectoral R\&D investment has about triple the effect on TFP change compared to diffused R\&D from other sectors. Indirect R\&D affects TFP change but the coefficients are significantly lower than in-sector R\&D. Additionally, the models with the FIE measures of TFP change performed better for the effects of in-sector technical progress measured by 
total sectoral R\&D expenditure and R\&D diffused by the other sectors of the economy. All $R \& D$ coefficients had the expected sign.

The value of the sectoral R\&D expenditure coefficient (0.29) is important for policymakers. It means that if R\&D expenditure is increased by $1 \%$ on average in all sectors, TFP growth will contribute to the total growth of the economy by (a conservative estimate ${ }^{10}$ of) $0.29 \%$ plus another $0.09 \%$ from the R\&D diffusion (indirect R\&D expenditures) ${ }^{11}$. The productivity of the Greek economy could be enhanced by higher R\&D expenditure combined with the necessary structural reforms to improve the efficiency of the innovation system, especially when the sectors with higher and positive TFP growth are given incentives to increase their investment in R\&D and/or government spending in projects related to R\&D. This policy targeting is specifically important during recession times because negative growth rates of an economy can be reduced or even turned to positive by enhancing TFP growth rates.

\section{Conclusions}

The paper provides a new approach to the neoclassical method for the measurement of total factor productivity change based on the full industry equilibrium methodology accounting for heterogeneous labor inputs, imported inputs, indirect taxes, and monopoly power. This is a completely new method that uses changes in prices as a basis to measure TFP growth and not changes in output used by the literature until now. Empirical findings from the application of the method to real-world data from the Greek economy are provided together with a comparison with those found by using the neoclassical approach to TFP change. Additionally, total sectoral R\&D and indirect R\&D diffused by other sectors of the economy were tested to be the main drivers of TFP change.

The empirical findings suggest that the FIE methodology (the price accounting approach) produces different sectoral TFP change results from the neoclassical approach. It was found that during the period examined, where the Greek economy was overwhelmed by a deep recession and consequently was characterized by systematic price decreases, the neoclassical approach underestimated sectoral TFP change, providing a less accurate measurement. Further, estimation results indicate that when the FIE approach for TFP change measurement is used for R\&D expenditure (total sectoral and diffused from other sectors) the quality of the model is higher than that using the neoclassical methodology for TFP change measurement.

Measuring productivity change in each industry of the Greek economy by applying the FIE methodology has economic policy significance because it showed that the effects of technical progress measured by R\&D expenditure on the disembodied productivity of the factors of production are different from the measures derived from the orthodox neoclassical economic theory. Specifically, in evaluating and comparing the results of the new technique with those of the neoclassical method, it became clear that TFP growth rates were systematically underestimated when employing the latter throughout the analyzed period, which was marked by a significant slump for the Greek economy. As a result, fifteen sectors that had positive TFP growth measured according to the approach proposed here would have been classified as having negative TFP growth if the standard in the literature approach had been used, leading policymakers to divert resources away from these sectors, slowing the economy's overall growth rate. Higher R\&D spending, combined with necessary structural reforms to improve the efficiency of the innovation system, could boost the productivity of the Greek economy, particularly if sectors with higher and positive TFP growth were given incentives to increase their investment in R\&D and/or government spending on R\&D projects. This policy targeting is especially crucial during recessions since improving TFP growth rates might help an economy's negative growth rates to be lowered or even turned positive. State intervention with targeted sectoral R\&D policy will be misleading if the neoclassical method has been used as a measurement of TFP change. This leads to quite different policy emphases in deciding R\&D tax breaks and direct R\&D 
investments, especially during periods of systematic price increases (decreases) where the neoclassical approach overestimates (underestimates) sectoral TFP changes.

Increased public R\&D spending, as well as incentives for the private sector to increase R\&D spending, could boost productivity and hence lead to economic growth. Parallel to this, the implementation of policies in Greece that encourage private R\&D investment and innovation will help the public sector make better use of its knowledge. More attention should be placed on improving R\&D capabilities, including human capital and infrastructure, strengthening relationships between small and medium-sized businesses, research institutions, and universities, establishing a venture capital market, and increasing labor mobility in this framework. This analysis should be expanded to include the following dimensions: first, more determinants of TFP growth, particularly human capital and R\&D diffused in the economy via trade flows and FDI (subject to data availability ${ }^{12}$ ); second, the results could be re-examined using regional data for the Greek economy; third, total sectoral R\&D expenditure was considered for five years in our analysis of the effects of $R \& D$ expenditure on TFP growth. R\&D capital is determined by applying a uniform discounting rate to R\&D expenses in time-series studies with a large number of years. This "radioactive" uniform depreciation across all sectors, on the other hand, has the disadvantage of being distant from the genuine one. It would be interesting to look at how Greece's economic adjustment program has altered the link between R\&D capital and TFP since 2010. No doubt the reader will think of other interesting and possible developments of the method introduced here.

Author Contributions: Conceptualization, I.S.; methodology, I.S. and N.T.; resources, N.T.; data curation, N.T.; applied work, N.T.; writing—original draft preparation, N.T. and I.S. All authors have read and agreed to the published version of the manuscript.

Funding: Financial assistance from research grant 80325 by the Research Committee of the University of Western Macedonia is gratefully acknowledged.

Institutional Review Board Statement: Not applicable.

Informed Consent Statement: Not applicable.

Data Availability Statement: Main datasets used by the study are publicly available from the Hellenic Statistical Authority: https:/ / www.statistics.gr/en/statistics/eco (accessed on 3 August 2021).

Conflicts of Interest: The authors declare no conflict of interest.

Appendix A. Descriptive Statistics for Measures of Sectoral TFP Change and Estimation Results from Equation (6)

Table A1. Descriptive statistics for $\gamma_{j}^{\prime}$ Laspeyres, $\gamma_{j}^{\prime}$ Paasche, and neoclassical TFP change.

\begin{tabular}{cccc}
\hline & $\begin{array}{c}\boldsymbol{\gamma}^{\prime}{ }_{j} \\
\text { Laspeyres }\end{array}$ & $\begin{array}{c}\boldsymbol{\gamma}_{j}^{\prime} \\
\text { Paasche }\end{array}$ & $\widehat{\mathbf{T F P}}_{j}^{\prime}$ \\
\hline Mean & $3.47 \times 10^{-18}$ & $5.20 \times 10^{-18}$ & -0.061147 \\
Median & 0.008359 & 0.000137 & -0.028878 \\
Maximum & 0.271632 & 0.705579 & 0.023373 \\
Minimum & -0.534969 & -0.516493 & -1.359287 \\
Std. Dev. & 0.129180 & 0.159255 & 0.176366 \\
Skewness & -1.182186 & 0.759561 & -6.476690 \\
Kurtosis & 7.015886 & 9.152843 & 47.56073 \\
\hline Jarque-Bera & 57.91358 & 107.1072 & 5742.530 \\
Probability & 0.000000 & 0.000000 & 0.000000 \\
\hline Sum & $1.11 \times 10^{-16}$ & $1.67 \times 10^{-16}$ & -3.913377 \\
Sum Sq. Dev. & 1.051307 & 1.597818 & 1.959617 \\
\hline Observations & 64 & 64 & 64 \\
\hline Source: Authors' calculations from Tables A3 and A4.
\end{tabular}

Source: Authors' calculations from Tables A3 and A4. 
Table A2. Estimation results from Equations (6) and (13).

\begin{tabular}{|c|c|c|c|c|c|c|}
\hline $\begin{array}{l}\text { Dependent } \\
\text { Variable }\end{array}$ & Regressand & $\begin{array}{l}\text { Coefficient } \\
\text { (Probability) }\end{array}$ & $\begin{array}{c}\text { Intercept } \\
\text { (Probability) }\end{array}$ & $R^{2}$ adj & $\begin{array}{l}\text { Breusch-Pagan-Godfrey } \\
\text { Heteroskedasticity Test: } \\
\text { F-Statistic (Prob. F(1,62)) }\end{array}$ & $\begin{array}{l}\text { Jarque-Bera } \\
\text { Normality Test } \\
\text { (Probability) }\end{array}$ \\
\hline$\gamma_{j}^{\prime}$ Laspeyres & $\widehat{S I}_{j}$ & $\begin{array}{c}-0.097537 \\
(0.0000)\end{array}$ & $\begin{array}{c}0.003836 \\
(0.0872)\end{array}$ & 0.329528 & $\begin{array}{c}0.408730 \\
(0.5250)\end{array}$ & $\begin{array}{c}57.91358 \\
(0.000000)\end{array}$ \\
\hline$\gamma_{j}^{\prime}$ Paasche & $\widehat{S I}_{j}$ & $\begin{array}{c}-0.097677 \\
(0.0000)\end{array}$ & $\begin{array}{c}0.019104 \\
(0.0948)\end{array}$ & 0.276400 & $\begin{array}{c}0.000572 \\
(0.9810)\end{array}$ & $\begin{array}{c}107.1072 \\
(0.000000)\end{array}$ \\
\hline$\widehat{T F P}_{j}^{\prime}$ & $\widehat{S I}_{j}$ & $\begin{array}{c}-0.098707 \\
(0.0000)\end{array}$ & $\begin{array}{l}0.022113 \\
(0.0625)\end{array}$ & 0.223828 & $\begin{array}{c}0.108699 \\
(0.7427)\end{array}$ & $\begin{array}{c}5742.530 \\
(0.000000)\end{array}$ \\
\hline
\end{tabular}

Source: Authors' estimations.

\section{Appendix B. TFP Change Calculated According to the FIE and the Neoclassical Approaches}

Table A3. TFP change calculated by the FIE approach.

\begin{tabular}{|c|c|c|c|c|c|c|c|}
\hline No & Sector Description & $\begin{array}{c}\gamma_{j}^{\prime} \\
\text { Laspeyres }\end{array}$ & Rank & $\begin{array}{c}\gamma_{j}^{\prime} \\
\text { Paasche }\end{array}$ & Rank & $\begin{array}{l}\text { Terms of Trade } \\
\text { Effect Laspeyres }\end{array}$ & $\begin{array}{l}\text { Terms of Trade } \\
\text { Effect Paasche }\end{array}$ \\
\hline 1 & $\begin{array}{c}\text { Products of agriculture, hunting, } \\
\text { and related services }\end{array}$ & 0.048 & 21 & -0.023 & 38 & 0.007 & 0.007 \\
\hline 2 & $\begin{array}{l}\text { Products of forestry, logging, and } \\
\text { related services }\end{array}$ & 0.132 & 9 & 0.091 & 14 & 0.005 & 0.002 \\
\hline 3 & $\begin{array}{l}\text { Fish and other fishing products; } \\
\text { aquaculture products; support } \\
\text { services to fishing }\end{array}$ & -0.067 & 50 & -0.092 & 52 & 0.005 & 0.004 \\
\hline 4 & Mining and quarrying & -0.120 & 59 & -0.132 & 57 & -0.050 & -0.051 \\
\hline 5 & $\begin{array}{l}\text { Food products, beverages, and } \\
\text { tobacco products }\end{array}$ & -0.040 & 43 & -0.045 & 44 & 0.015 & 0.014 \\
\hline 6 & $\begin{array}{l}\text { Textiles, wearing apparel, and } \\
\text { leather products }\end{array}$ & 0.068 & 15 & 0.078 & 15 & 0.032 & 0.038 \\
\hline 7 & $\begin{array}{l}\text { Wood and products of wood and } \\
\text { cork, except furniture; articles of } \\
\text { straw and plaiting materials }\end{array}$ & -0.001 & 34 & 0.060 & 18 & 0.015 & 0.020 \\
\hline 8 & Paper and paper products & 0.010 & 32 & -0.002 & 33 & 0.015 & 0.014 \\
\hline 9 & Printing and recording services & 0.134 & 8 & 0.129 & 8 & 0.000 & 0.000 \\
\hline 10 & $\begin{array}{l}\text { Coke and refined petroleum } \\
\text { products }\end{array}$ & -0.535 & 64 & -0.516 & 64 & -0.037 & -0.042 \\
\hline 11 & Chemicals and chemical products & 0.144 & 7 & 0.131 & 7 & 0.031 & 0.031 \\
\hline 12 & $\begin{array}{l}\text { Basic pharmaceutical products and } \\
\text { pharmaceutical preparations }\end{array}$ & -0.047 & 45 & -0.065 & 49 & -0.095 & -0.093 \\
\hline 13 & Rubber and plastics products & 0.012 & 30 & 0.012 & 28 & 0.011 & 0.011 \\
\hline 14 & $\begin{array}{l}\text { Other non-metallic mineral } \\
\text { products }\end{array}$ & 0.007 & 33 & 0.009 & 31 & 0.005 & 0.006 \\
\hline 15 & Basic metals & 0.044 & 23 & 0.057 & 19 & 0.000 & 0.000 \\
\hline 16 & $\begin{array}{l}\text { Fabricated metal products, except } \\
\text { machinery and equipment }\end{array}$ & 0.016 & 29 & 0.022 & 24 & 0.002 & 0.003 \\
\hline 17 & $\begin{array}{l}\text { Computer, electronic, and optical } \\
\text { products }\end{array}$ & 0.027 & 26 & 0.011 & 29 & -0.004 & -0.004 \\
\hline 18 & Electrical equipment & 0.119 & 11 & 0.109 & 11 & 0.018 & 0.018 \\
\hline 19 & Machinery and equipment n.e.c. & 0.046 & 22 & 0.036 & 21 & 0.022 & 0.023 \\
\hline
\end{tabular}


Table A3. Cont.

\begin{tabular}{|c|c|c|c|c|c|c|c|}
\hline No & Sector Description & $\begin{array}{c}\gamma_{j}^{\prime} \\
\text { Laspeyres }\end{array}$ & Rank & $\begin{array}{c}\gamma_{j}^{\prime} \\
\text { Paasche }\end{array}$ & Rank & $\begin{array}{l}\text { Terms of Trade } \\
\text { Effect Laspeyres }\end{array}$ & $\begin{array}{l}\text { Terms of Trade } \\
\text { Effect Paasche }\end{array}$ \\
\hline 20 & $\begin{array}{l}\text { Motor vehicles, trailers, and } \\
\text { semi-trailers }\end{array}$ & 0.127 & 10 & 0.116 & 10 & -0.009 & -0.009 \\
\hline 21 & Other transport equipment & 0.145 & 6 & 0.133 & 6 & 0.000 & 0.000 \\
\hline 22 & $\begin{array}{l}\text { Furniture; other manufactured } \\
\text { goods }\end{array}$ & 0.102 & 12 & 0.104 & 12 & 0.007 & 0.007 \\
\hline 23 & $\begin{array}{c}\text { Repair and installation services of } \\
\text { machinery and equipment }\end{array}$ & 0.029 & 24 & 0.014 & 25 & 0.000 & 0.000 \\
\hline 24 & $\begin{array}{l}\text { Electricity, gas, steam, and } \\
\text { air-conditioning }\end{array}$ & -0.240 & 62 & -0.338 & 63 & -0.009 & -0.010 \\
\hline 25 & $\begin{array}{l}\text { Natural water; water treatment and } \\
\text { supply services }\end{array}$ & -0.053 & 47 & -0.012 & 35 & 0.000 & 0.000 \\
\hline 26 & $\begin{array}{l}\text { Sewerage; waste collection, } \\
\text { treatment, and disposal activities; } \\
\text { materials recovery; remediation } \\
\text { activities and other waste } \\
\text { management services }\end{array}$ & -0.013 & 39 & 0.010 & 30 & 0.003 & 0.002 \\
\hline 27 & $\begin{array}{l}\text { Constructions and construction } \\
\text { works }\end{array}$ & -0.059 & 49 & -0.062 & 46 & 0.000 & 0.000 \\
\hline 28 & $\begin{array}{l}\text { Wholesale and retail trade and } \\
\text { repair services of motor vehicles } \\
\text { and motorcycles }\end{array}$ & -0.018 & 41 & -0.034 & 41 & 0.000 & 0.000 \\
\hline 29 & $\begin{array}{l}\text { Wholesale trade services, except of } \\
\text { motor vehicles and motorcycles }\end{array}$ & 0.011 & 31 & 0.002 & 32 & 0.000 & 0.000 \\
\hline 30 & $\begin{array}{l}\text { Retail trade services, except of } \\
\text { motor vehicles and motorcycles }\end{array}$ & 0.049 & 20 & 0.026 & 23 & 0.000 & 0.000 \\
\hline 31 & $\begin{array}{l}\text { Land transport services and } \\
\text { transport services via pipelines }\end{array}$ & -0.164 & 61 & -0.218 & 61 & 0.001 & 0.001 \\
\hline 32 & Water transport services & -0.010 & 36 & -0.027 & 39 & 0.000 & 0.000 \\
\hline 33 & Air transport services & 0.193 & 4 & 0.261 & 3 & 0.041 & 0.079 \\
\hline 34 & $\begin{array}{l}\text { Warehousing and support services } \\
\text { for transportation }\end{array}$ & -0.010 & 37 & -0.046 & 45 & 0.003 & 0.002 \\
\hline 35 & Postal and courier services & 0.065 & 17 & 0.069 & 16 & 0.003 & 0.003 \\
\hline 36 & Accommodation and food services & -0.041 & 44 & -0.042 & 43 & 0.000 & 0.000 \\
\hline 37 & Publishing services & -0.098 & 54 & -0.139 & 59 & -0.002 & -0.003 \\
\hline 38 & $\begin{array}{l}\text { Motion picture, video and } \\
\text { television program production } \\
\text { services, sound recording and } \\
\text { music publishing; programming } \\
\text { and broadcasting services }\end{array}$ & -0.051 & 46 & -0.063 & 47 & -0.011 & -0.018 \\
\hline 39 & Telecommunications services & -0.010 & 38 & -0.021 & 37 & -0.002 & -0.002 \\
\hline 40 & $\begin{array}{c}\text { Computer programming, } \\
\text { consultancy and related services; } \\
\text { information services }\end{array}$ & -0.007 & 35 & -0.020 & 36 & -0.006 & -0.004 \\
\hline 41 & $\begin{array}{c}\text { Financial services, except insurance } \\
\text { and pension funding }\end{array}$ & -0.027 & 42 & -0.039 & 42 & -0.001 & -0.001 \\
\hline 42 & $\begin{array}{l}\text { Insurance, reinsurance and pension } \\
\text { funding services, except } \\
\text { compulsory social security }\end{array}$ & 0.066 & 16 & 0.065 & 17 & -0.034 & -0.023 \\
\hline
\end{tabular}


Table A3. Cont.

\begin{tabular}{|c|c|c|c|c|c|c|c|}
\hline No & Sector Description & $\begin{array}{c}\gamma_{j}^{\prime} \\
\text { Laspeyres }\end{array}$ & Rank & $\begin{array}{c}\gamma_{j}^{\prime} \\
\text { Paasche }\end{array}$ & Rank & $\begin{array}{l}\text { Terms of Trade } \\
\text { Effect Laspeyres }\end{array}$ & $\begin{array}{l}\text { Terms of Trade } \\
\text { Effect Paasche }\end{array}$ \\
\hline 43 & $\begin{array}{c}\text { Services auxiliary to financial } \\
\text { services and insurance services }\end{array}$ & -0.074 & 52 & -0.063 & 48 & 0.000 & 0.000 \\
\hline 44 & $\begin{array}{l}\text { Real estate activities without } \\
\text { imputed rents }\end{array}$ & 0.245 & 2 & 0.706 & 1 & 0.000 & 0.000 \\
\hline 45 & Imputed rents & 0.203 & 3 & 0.183 & 5 & 0.000 & 0.000 \\
\hline 46 & $\begin{array}{l}\text { Legal and accounting services; } \\
\text { services of head offices; } \\
\text { management consulting services }\end{array}$ & -0.123 & 60 & -0.110 & 55 & -0.001 & -0.001 \\
\hline 47 & $\begin{array}{c}\text { Architectural and engineering } \\
\text { services; technical testing and } \\
\text { analysis services }\end{array}$ & -0.071 & 51 & -0.081 & 50 & 0.000 & 0.000 \\
\hline 48 & $\begin{array}{l}\text { Scientific research and } \\
\text { development services }\end{array}$ & -0.115 & 57 & -0.117 & 56 & 0.000 & 0.000 \\
\hline 49 & $\begin{array}{c}\text { Advertising and market research } \\
\text { services }\end{array}$ & -0.087 & 53 & -0.101 & 53 & 0.000 & 0.000 \\
\hline 50 & $\begin{array}{c}\text { Other professional, scientific and } \\
\text { technical services; veterinary } \\
\text { services }\end{array}$ & 0.022 & 28 & 0.043 & 20 & -0.002 & -0.002 \\
\hline 51 & Rental and leasing services & 0.100 & 13 & 0.092 & 13 & -0.023 & -0.008 \\
\hline 52 & Employment services & -0.368 & 63 & -0.301 & 62 & 0.000 & 0.000 \\
\hline 53 & $\begin{array}{c}\text { Travel agency, tour operator and } \\
\text { other reservation services and } \\
\text { related services }\end{array}$ & 0.029 & 25 & 0.013 & 26 & 0.000 & 0.000 \\
\hline 54 & $\begin{array}{l}\text { Security and investigation services; } \\
\text { services to buildings and landscape; } \\
\text { office administrative, office support } \\
\text { and other business support services }\end{array}$ & -0.113 & 55 & -0.101 & 54 & -0.001 & -0.001 \\
\hline 55 & $\begin{array}{l}\text { Public administration and defense } \\
\text { services; compulsory social security } \\
\text { services }\end{array}$ & 0.026 & 27 & 0.013 & 27 & 0.000 & 0.000 \\
\hline 56 & Education services & -0.017 & 40 & -0.029 & 40 & 0.000 & 0.000 \\
\hline 57 & Human health services & -0.053 & 48 & -0.081 & 51 & 0.000 & 0.000 \\
\hline 58 & Social work services & -0.113 & 56 & -0.208 & 60 & 0.000 & 0.000 \\
\hline 59 & $\begin{array}{l}\text { Creative, arts, and entertainment } \\
\text { services; library, archive, museum } \\
\text { and other cultural services; } \\
\text { gambling and betting services }\end{array}$ & 0.056 & 18 & -0.003 & 34 & -0.005 & -0.001 \\
\hline 60 & $\begin{array}{l}\text { Sporting services and amusement } \\
\text { and recreation services }\end{array}$ & 0.182 & 5 & 0.200 & 4 & 0.000 & 0.000 \\
\hline 61 & $\begin{array}{l}\text { Services furnished by membership } \\
\text { organizations }\end{array}$ & 0.272 & 1 & 0.315 & 2 & 0.000 & 0.000 \\
\hline 62 & $\begin{array}{l}\text { Repair services of computers and } \\
\text { personal and household goods }\end{array}$ & 0.077 & 14 & 0.119 & 9 & 0.000 & 0.000 \\
\hline 63 & Other personal services & 0.056 & 19 & 0.034 & 22 & 0.000 & 0.000 \\
\hline 64 & $\begin{array}{l}\text { Services of households as } \\
\text { employers; undifferentiated goods } \\
\text { and services produced by } \\
\text { households for own use }\end{array}$ & -0.119 & 58 & -0.132 & 58 & 0.000 & 0.000 \\
\hline
\end{tabular}


Table A4. TFP change measured according to the neoclassical approach.

\begin{tabular}{|c|c|c|c|}
\hline & Sector Description & $\widehat{T F P}_{j}^{\prime}$ & Rank \\
\hline 1 & Products of agriculture, hunting, and related services & 0.006 & 11 \\
\hline 2 & Products of forestry, logging, and related services & 0.019 & 3 \\
\hline 3 & Fish and other fishing products; aquaculture products; support services to fishing & -0.030 & 34 \\
\hline 4 & Mining and quarrying & -0.400 & 63 \\
\hline 5 & Food products, beverages, and tobacco products & -0.037 & 38 \\
\hline 6 & Textiles, wearing apparel, and leather products & -0.019 & 26 \\
\hline 7 & Wood and products of wood and cork, except furniture; articles of straw and plaiting materials & -0.148 & 62 \\
\hline 8 & Paper and paper products & -0.051 & 44 \\
\hline 9 & Printing and recording services & -0.040 & 41 \\
\hline 10 & Coke and refined petroleum products & -1.359 & 64 \\
\hline 11 & Chemicals and chemical products & 0.014 & 5 \\
\hline 12 & Basic pharmaceutical products and pharmaceutical preparations & -0.124 & 59 \\
\hline 13 & Rubber and plastics products & -0.010 & 22 \\
\hline 14 & Other non-metallic mineral products & -0.055 & 47 \\
\hline 15 & Basic metals & 0.002 & 17 \\
\hline 16 & Fabricated metal products, except machinery and equipment & -0.018 & 25 \\
\hline 17 & Computer, electronic, and optical products & 0.003 & 13 \\
\hline 18 & Electrical equipment & 0.009 & 8 \\
\hline 19 & Machinery and equipment n.e.c. & 0.002 & 15 \\
\hline 20 & Motor vehicles, trailers, and semi-trailers & 0.002 & 14 \\
\hline 21 & Other transport equipment & 0.011 & 6 \\
\hline 22 & Furniture; other manufactured goods & -0.005 & 21 \\
\hline 23 & Repair and installation services of machinery and equipment & 0.001 & 18 \\
\hline 24 & Electricity, gas, steam, and air-conditioning & -0.083 & 53 \\
\hline 25 & Natural water; water treatment and supply services & -0.028 & 32 \\
\hline 26 & $\begin{array}{l}\text { Sewerage; waste collection, treatment, and disposal activities; materials recovery; remediation } \\
\text { activities and other waste management services }\end{array}$ & -0.036 & 37 \\
\hline 27 & Constructions and construction works & -0.119 & 58 \\
\hline 28 & Wholesale and retail trade and repair services of motor vehicles and motorcycles & -0.069 & 50 \\
\hline 29 & Wholesale trade services, except for motor vehicles and motorcycles & -0.013 & 24 \\
\hline 30 & Retail trade services, except for motor vehicles and motorcycles & -0.023 & 28 \\
\hline 31 & Land transport services and transport services via pipelines & -0.067 & 49 \\
\hline 32 & Water transport services & -0.010 & 23 \\
\hline 33 & Air transport services & 0.008 & 9 \\
\hline 34 & Warehousing and support services for transportation & -0.020 & 27 \\
\hline 35 & Postal and courier services & -0.092 & 55 \\
\hline 36 & Accommodation and food services & -0.046 & 43 \\
\hline 37 & Publishing services & -0.097 & 57 \\
\hline 38 & $\begin{array}{l}\text { Motion picture, video, and television program production services, sound recording and music } \\
\text { publishing; programming and broadcasting services }\end{array}$ & -0.095 & 56 \\
\hline 39 & Telecommunications services & -0.040 & 42 \\
\hline
\end{tabular}


Table A4. Cont.

\begin{tabular}{|c|c|c|c|}
\hline & Sector Description & $\widehat{T F P}_{j}^{\prime}$ & Rank \\
\hline 40 & Computer programming, consultancy, and related services; information services & -0.037 & 39 \\
\hline 41 & Financial services, except insurance and pension funding & -0.053 & 46 \\
\hline 42 & Insurance, reinsurance, and pension funding services, except compulsory social security & -0.089 & 54 \\
\hline 43 & Services auxiliary to financial services and insurance services & -0.030 & 33 \\
\hline 44 & Real estate activities without imputed rents & 0.018 & 4 \\
\hline 45 & Imputed rents & 0.010 & 7 \\
\hline 46 & Legal and accounting services; services of head offices; management consulting services & -0.052 & 45 \\
\hline 47 & Architectural and engineering services; technical testing and analysis services & -0.057 & 48 \\
\hline 48 & Scientific research and development services & -0.078 & 52 \\
\hline 49 & Advertising and market research services & -0.026 & 30 \\
\hline 50 & Other professional, scientific, and technical services; veterinary services & -0.028 & 31 \\
\hline 51 & Rental and leasing services & 0.006 & 10 \\
\hline 52 & Employment services & -0.147 & 61 \\
\hline 53 & Travel agency, tour operator, and other reservation services and related services & 0.002 & 16 \\
\hline 54 & $\begin{array}{l}\text { Security and investigation services; services to buildings and landscape; office administrative, } \\
\text { office support, and other business support services }\end{array}$ & -0.030 & 35 \\
\hline 55 & Public administration and defense services; compulsory social security services & -0.002 & 19 \\
\hline 56 & Education services & -0.025 & 29 \\
\hline 57 & Human health services & -0.039 & 40 \\
\hline 58 & Social work services & -0.076 & 51 \\
\hline 59 & $\begin{array}{l}\text { Creative, arts and entertainment services; library, archive, museum, and other cultural services; } \\
\text { gambling and betting services }\end{array}$ & 0.005 & 12 \\
\hline 60 & Sporting services and amusement and recreation services & 0.021 & 2 \\
\hline 61 & Services furnished by membership organizations & 0.023 & 1 \\
\hline 62 & Repair services of computers and personal and household goods & -0.003 & 20 \\
\hline 63 & Other personal services & -0.034 & 36 \\
\hline 64 & $\begin{array}{c}\text { Services of households as employers; undifferentiated goods and services produced by } \\
\text { households for own use }\end{array}$ & -0.138 & 60 \\
\hline
\end{tabular}

Negative change rates in red. Source: Authors' calculations.

Appendix C. Test of the Equality of Means and Medians of TFP Change Measured According to the Neoclassical and FIE Approaches

\begin{tabular}{rcc}
\hline & $\widehat{\text { TFP }}$ vs. $\gamma^{\prime}$ Laspeyres & $\widehat{\text { TFP } \text { vs. } \gamma^{\prime} \text { Paasche }}$ \\
\hline Test for Equality of Means & 5.006844 & 4.237668 \\
Anova F-test, significance level in parentheses & $(0.0272)$ & $(0.0416)$ \\
\hline Test for Equality of Medians & 9.565793 & 6.093841 \\
Kruskal-Wallis, significance level in parentheses & $(0.0020)$ & $(0.0136)$ \\
\hline Test for Equality of Medians & 9.565793 & 6.093841 \\
Kruskal-Wallis (tie-adj.), significance level in parentheses & $(0.0020)$ & $(0.0136)$ \\
\hline Test for Equality of Medians & 9.938526 & 6.613421 \\
van der Waerden, significance level in parentheses & $(0.0016)$ & $(0.0101)$ \\
\hline
\end{tabular}




\section{Notes}

1 In the empirical work that follows it is considered that this assumption cannot be applied to real-world data. The existence of monopoly power is acknowledged and its effects on prices is isolated using regression analysis.

2 Following Leontief's methodology (Leontief 1986) $\boldsymbol{R} \boldsymbol{D} \_\boldsymbol{D I F}=\boldsymbol{R} \boldsymbol{D}^{\prime}\left(\boldsymbol{I}-\boldsymbol{A}^{*}\right)^{-1}-\boldsymbol{R} \boldsymbol{D}$. RD_DIF $F_{j}$ is the jth element of $\boldsymbol{R} \boldsymbol{D} \_\boldsymbol{D I F}$.

3 See Opocher and Steedman (2015, pp. 161-63) and Sakurai et al. (1996, pp. 36-38) for the relevant discussion.

$4 \widehat{T F P_{j}^{\prime}}$ throughout the paper is used to denote the per centage change in sectoral TFP calculated according to the neoclassical methodology.

5 See Section 3 Results and Discussion for a further explanation on this.

6 See Opocher and Steedman (2015, pp. 162-63) for its theoretical proof.

$7 \quad$ TFP' change according to the neoclassical approach was estimated from (13) and the results are reported in Appendix B.

8 These sectors are: 6 Textiles, wearing apparel and leather products, 8 Paper and paper products, 9 Printing and recording services, 13 Rubber and plastics products, 14 Other non-metallic mineral products, 16 Fabricated metal products, 22 Furniture, 29 Wholesale trade services, 30 Retail trade services, 35 Postal and courier services, 42 Insurance, 50 Other professional, scientific and technical services, 55 Public administration and defence services, 62 Repair services of computers, 63 Other personal services.

9 If a model is more than 2 AIC units lower than another, it is considered significantly better than that model.

10 By 'conservatives estimates' we mean the coefficients eatimated when TFP growth was calculated according to the Paasche method of base year since these are systematically lower that those calculated accoring to the Laspeyres method of base year.

11 Since, the estimation results were obtained by total R\&D expedtiture over the period 2010-2015 an 1\% increase in R\& expenditure does not refer to the annual figures but to the total five-year period.

12 It was not possible to include in the present paper the effects of R\&D diffusion from abroad because import matrices were not available.

\section{References}

Agiomirgianakis, George, Georg Bertsatos, and Nicholas Tsounis. 2019. Gender Wage Gaps and Economic Crisis in Greece. International Review of Applied Economics 33: 254-76. [CrossRef]

Akinlo, Anthony Enisan, and Omowumi Adejumo. 2016. Determinants of Total Factor Productivity Growth in Nigeria, 1970-2009. Global Business Review 17: 257-70. [CrossRef]

Amri, Fethi, Younes Ben Zaied, and Bechir Ben Lahouel. 2019. ICT, total factor productivity, and carbon dioxide emissions in Tunisia. Technological Forecasting and Social Change 146: 212-17. [CrossRef]

Arazmuradov, Annageldy, Gianmaria Martini, and Davide Scotti. 2014. Determinants of total factor productivity in former Soviet Union economies: A stochastic frontier approach. Economic Systems 38: 115-35. [CrossRef]

Athanasoglou, Panayiotis, Evangelia Georgiou, and Christos Staikouras. 2008. Assessing Output and Productivity Growth in the Banking Industry. Working Paper. Athens: Bank of Greece.

Aulin-Ahmavaara, Pirkko. 2004. Aggregation of Industry-Level TFP-measures. Paper presented at the International Conference on Input-Output and General Equilibrium: Data, Modeling and Policy Analysis, Jointly Organized by the EcoMod Network and the IIOA, Free University of Brussels, Brussels, Belgium, September 2-4.

Bernstein, Jeffrey, and Pierre Mohnen. 1994. International RED Spillovers between US and Japanese RED Intensive Sectors. NBER Working Paper No. 4682. New York: NBER.

Bhattacharya, Mita, Luka Emeka Okafor, and Pradeep Valarmathi. 2021. International firm activities, R\&D, and productivity: Evidence from Indian manufacturing firms. Economic Modelling 97: 1-13.

Bournakis, Ioannis. 2012. Sources of TFP growth in a framework of convergence-evidence from Greece. International Review of Applied Economics 26: 47-72. [CrossRef]

Coe, David, and Elhanan Helpman. 1993. International RED Spillovers. NBER Working Paper Series No. 4444; New York: NBER.

Comin, Diego. 2010. Total Factor Productivity. In Economic Growth. The New Palgrave Economics Collection. Edited by Steven Durlauf and Lawrence Blume. London: Palgrave Macmillan. [CrossRef]

Danska-Borsiak, Barbara. 2018. Determinants of total factor productivity in Visegrad Group nuts-2 regions. Acta Oeconomica 68: 31-50.

Donghyun, Oh, Almas Heshmati, and Hans Lööf. 2014. Total factor productivity of Korean manufacturing industries: Comparison of competing models with firm-level data. Japan and the World Economy 30: 25-36.

Doumi, Ali. 2017. Measurement of Total Factor Productivity in Agriculture: Study on a Panel of Mediterranean Countries (1980-2012). Journal of International and Global Economic Studies 9: 41-56.

Eberhardt, Markus, Christian Helmers, and Hubert Strauss. 2013. Do spillovers matter when estimating private returns to R\&D? Review of Economics and Statistics 95: 436-48.

Edquist, Harald, and Magnus Henrekson. 2006. Technological breakthroughs and productivity growth. Research in Economic History 24: $1-53$. 
Gehringeer, Agnieszka, Inmaculada Martínez-Zarzoso, and Felicitas Nowak-Lehmann Danzinger. 2015. What are the drivers of total factor productivity in the European Union? Economics of Innovation and New Technology 25: 406-34. [CrossRef]

Giang, Mai Huong, Tran Dang Xuan, Bui Huy Trung, and Mai Thanh Que. 2019. Total Factor Productivity of Agricultural Firms in Vietnam and Its Relevant Determinants. Economies 7: 4. [CrossRef]

Gogos, Stylianos, Nikolaos Mylonidis, Dimitris Papageorgiou, and Vanghelis Vassilatos. 2013. 1979-2001: A Greek great depression through the lens of neoclassical growth theory. Economic Modelling 36: 316-31. [CrossRef]

Gollop, Frank, and Dale Jorgenson. 1980. U.S. Productivity Growth by Industry, 1947-1973. In New Developments in Productivity Measurement and Analysis. Edited by John Kendrick and Beatrice Vaccara. Chicago: University of Chicago Press.

Griffith, Rachel, Stephen James Redding, and John Van Reenen. 2004. Mapping the two faces of R\&D: Productivity growth in a panel of OECD industries. Review of Economics and Statistics 86: 883-95.

Griliches, Zvi. 1979. Issues in assessing the contribution of research and development to productivity growth. Bell Journal of Economics 10: 92-116. [CrossRef]

Griliches, Zvi. 1992. The Search for R\&D Spillovers. The Scandinavian Journal of Economics 94: 29-47. [CrossRef]

Griliches, Zvi. 1994. Productivity, R\&D and the data constraint. American Economic Review 84: 1-23.

Haider, Franz, Robert Kunst, and Franz Wirl. 2021. Total factor productivity, its components and drivers. Empirica 48: $283-327$. [CrossRef]

Haider, Salman, Aadil Ganaie, and Bandi Kamaiah. 2019. Total factor productivity and openness in Indian economy: 1970-2011. Foreign Trade Review 54: 46-57.

Hall, Bronwyn, Jacques Mairesse, and Pierre Mohnen. 2009. Measuring the Returns to RED. NBER Working Paper No. 15622. Cambridge: National Bureau of Economic Research.

Harris, Richard, and John Moffat. 2020. The impact of product subsidies on plant-level total factor productivity in Britain, 1997-2014. Scottish Journal of Political Economy 67: 387-403. [CrossRef]

Hellenic Statistical Authority. 2010. Input-Output Tables. Athens: Hellenic Statistical Authority.

Hellenic Statistical Authority. 2015. Input-Output Tables. Athens: Hellenic Statistical Authority.

Hellenic Statistical Authority. 2016a. Annual Average Indices of Import Price Index. Athens: Hellenic Statistical Authority.

Hellenic Statistical Authority. 2016b. Annual Consumer Price Indices. Athens: Hellenic Statistical Authority.

Hirschman, Albert. 1964. The Paternity of an Index. The American Economic Review 54: 761-62.

Huang, Junbing, Xiaochen Cai, Shuo Huang, Sen Tian, and Hongyan Lei. 2019. Technological factors and total factor productivity in China: Evidence based on a panel threshold model. China Economic Review 54: 271-85. [CrossRef]

International Monetary Fund (IMF). 2021. World Economic Outlook (WEO) Database. Washington: IMF Pubmications.

Jones, Charles, and Paul Michael Romer. 2010. The New Kaldor Facts: Ideas, Institutions, Population, and Human Capital. American Economic Journal: Macroeconomics 2: 224-45. [CrossRef]

Jorgenson, Dale, and Zvi Griliches. 1967. The Explanation of Productivity Change. The Review of Economic Studies 34: 249-83. [CrossRef]

Katsoulacos, Yannis, and Nicholas Tsounis. 2000. Knowledge Intensive Business Services and Productivity Growth: The Greek Evidence. In Services and the Knowledge-Based Economy. Edited by Mark Boden and Ian Miles. London: Continuum, Chapter 11.

Kéïta, Kouramoudou, and Laurila Hannu. 2021. Corruption and Tax Burden: What Is the Joint Effect on Total Factor Productivity? Economies 9: 26. [CrossRef]

Kim, Sangho. 2016. Factor determinants of total factor productivity growth for the Japanese manufacturing industry. Contemporary Economic Policy 34: 572-86. [CrossRef]

Kydland, Finn, and Edward Prescott. 1982. Time to Build and Aggregate Fluctuations. Econometrica 50: 1345-70. [CrossRef]

Leontief, Wassili. 1986. Input-Output Economics. New York: Oxford University Press.

Lerner, Abba. 1934. The Concept of Monopoly and the Measurement of Monopoly Power. The Review of Economic Studies 1: 157-75. [CrossRef]

Lucas, Robert. 1988. On the mechanics of economic development. Journal of Monetary Economics 22: 3-42. [CrossRef]

Manasse, Paolo. 2016. Lessons for Europe from the Greek Crisis. In A New Growth Model for the Greek Economy. Edited by Panagiotis Petrakis. New York: Palgrave Macmillan, Chapter 5.

Mohnen, Pierre. 1989. New Technologies and Inter-Industry Spillovers. In STI Review. Paris: OECD, pp. 131-47.

Nadiri, Ishaq. 1993. Innovations and Technological Spillovers. NBER Working Paper No. 4423. New York: NBER.

Ngo, Quang-Thanh, Quang-Van Tran, Tien-Dung Nguyen, and Trung-Thanh Nguyen. 2020. How Heterogeneous Are the Determinants of Total Factor Productivity in Manufacturing Sectors? Panel-Data Evidence from Vietnam. Economies 8: 57. [CrossRef]

OECD. 2011-2015. R-D Expenditure by Industry. Paris: OECD.

Opocher, Arrigo. 2010. Measuring Productivity Increase by Long-run Prices: The Early Analyses of G.R. Porter and R.Giffen. European Journal of the History of Economic Thought 17: 1271-91. [CrossRef]

Opocher, Arrigo, and Ian Steedman. 2015. Full Industry Equilibrium: A Theory of the Industrial Long Run. Cambridge: Cambridge University Press.

Otsuka, Akihiro. 2017. Regional determinants of total factor productivity in Japan: Stochastic frontier analysis. Annals of Regional Science 58: 579-96. [CrossRef]

Pegkas, Panagiotis, Christos Staikouras, and Constantinos Tsamadias. 2020. Does Domestic and Foreign R\&D Capital Affect Total Factor Productivity? Evidence from Eurozone Countries. International Economic Journal 34: 258-78. 
Próchniak, Mariusz. 2016. Changes in Total Factor Productivity. In The Role of Economic Policy and Institutions. Edited by Marzenna Weresa, Zbigniew Matkowski and Ryszard Rapacki. Warsaw: World Economy Research Institute, SGH Warsaw School of Economics.

Romer, Paul Michael. 1986. Increasing Returns and Long-Run Growth. Journal of Political Economy 94: 1002-37. [CrossRef]

Romer, Paul Michael. 1994. The Origins of Endogenous Growth. Journal of Economic Perspectives 8: 3-22. [CrossRef]

Sakurai, Norihisa, Evangelos Ioannidis, and George Papaconstantinou. 1996. The Impact of RED and Technology Diffusion on Productivity Growth: Evidence for 10 OECD Countries in the 1970s and 1980s. OECD Science, Technology and Industry Working Papers, $1996 / 02$. Paris: OECD Publishing. [CrossRef]

Saleem, Hummera, Malik Shahzad, Muhammad Bilar Khan, and Bashir Ahmad Khilji. 2019. Innovation, total factor productivity and economic growth in Pakistan: A policy perspective. Economic Structures 8: 7. [CrossRef]

Schmalensee, Richard. 1977. Using the H-Index of concentration with published data. Review of Economics and Statistics 59: 186-93. [CrossRef]

Shabbir, Malik Shahzad, and Nusrat Yaqoob. 2019. The impact of technological advancement on total factor productivity of cotton: A comparative analysis between Pakistan and India. Journal of Economic Structures 8: 1-16. [CrossRef]

Sharif, Naubahar, Kevin Chandra, Athar Mansoor, and Kirti Sinha. 2021. A comparative analysis of research and development spending and total factor productivity growth in Hong Kong, Shenzhen, Singapore. Structural Change and Economic Dynamics 57: 108-20. [CrossRef]

Sheather, Simon. 2009. A Modern Approach to Regression with R. New York: Springer.

Shen, Yongchang, Shujing Yue, Shiqian Sun, and Mengqi Guo. 2020. Sustainable total factor productivity growth: The case of China. Journal of Cleaner Production 256: 120727. [CrossRef]

Sheng, Yu, and Ligang Song. 2013. Re-estimation of firms' total factor productivity in China's iron and steel industry. China Economic Review 24: 177-88. [CrossRef]

Silveira, Naijela Janaina Costa, Diogo Ferraz, Diego Scarpa de Mello, Eduardo Polloni-Silva, Herick Fernando Moralles, and Daisy Rebelatto. 2021. Calculating Models for Total Factor Productivity Measurement. Exacta. [CrossRef]

Solow, Robert. 1956. A Contribution to the Theory of Economic Growth. The Quarterly Journal of Economics 70: 65-94. [CrossRef]

Tsamadias, Constantinos, Panagiotis Pegkas, Emmanuel Mamatzakis, and Christos Staikouras. 2019. Does R\&D, human capital and FDI matter for TFP in OECD countries? Economics of Innovation and New Technology 28: 386-406.

Tsekouras, Kostas, and Irene Daskalopoulou. 2006. Market Concentration and Multifaceted and Productive Efficiency. Journal of Productivity Analysis 25: 79-91. [CrossRef]

Vamvakidis, Athanasios. 2002. How Robust is the Growth-Openness Connection? Historical Evidence. Journal of Economic Growth 7: 57-80. [CrossRef]

Venturini, Francesco. 2015. The modern drivers of productivity. Research Policy 44: 357-69. [CrossRef]

Vournakis, Ioannis. 2007. Productivity Convergence between Greece and Germany, What Is the Role for Trade and R\&D. Paper presented at Ninth Annual Conference, European Trade Study Group, Athens, Greece, September 13-15.

Voutsinas, Ioannis, and Constantinos Tsamadias. 2014. Does research and development capital affect total factor productivity? Evidence from Greece. Economics of Innovation and New Technology 23: 17-36. [CrossRef]

Yue, Shujing, Yongchang Shen, and Jianhong Yuan. 2019. Sustainable total factor productivity growth for 55 states: An application of the new malmquist index considering ecological footprint and human development index. Resources Conservation and Recycling 146: 475-83. [CrossRef] 